A N N A L ES

UNIVERSITATIS MARIAE CURIE-SKŁODOWSKA

LUBLIN - POLONIA

VOL. LXII, 2

SECTIO G

2015

JUSTYNA CZERNIAK-SWĘDZIOŁ

\title{
Równe i sprawiedliwe zatrudnienie na podstawie umowy o pracę na zastępstwo?
}

Equal and Fair Employment Treatment for Those on Replacement

Employment Contracts?

\section{WSTĘP}

W myśl Konstytucji $\mathrm{RP}^{1}$ wszyscy są równi wobec prawa i mają prawo do równego traktowania przez władze publiczne. Nikt nie może być dyskryminowany w życiu politycznym, społecznym lub gospodarczym z jakiejkolwiek przyczyny. Rzeczpospolita Polska jako demokratyczne państwo prawne winna urzeczywistniać zasadę sprawiedliwości społecznej². Z kolei prawo pracy ma na celu realizować (chronić) takie wartości, jak godność, wolność, sprawiedliwość, równość, solidarność, życie i zdrowie, rodzina oraz prawo do pracy³. W świetle dwóch z powyższych zasad, tj. równości i sprawiedliwości, postaram się dokonać całościowej analizy zatrudnienia w oparciu o umowę o pracę na zastępstwo, ukazując wszelkie niedoskonałości tej regulacji, niejednokrotnie naruszającej podstawowe zasady prawa pracy i Konstytucji.

W Kodeksie pracy od 2002 roku $^{4}$ istnieją przepisy umożliwiające zatrudnienie pracownika (zastępcy) na czas usprawiedliwionej nieobecności innego pracownika w oparciu o umowę o pracę na czas określony, obejmujący czas tej

1 Art. 32 Konstytucji Rzeczypospolitej Polskiej z dnia 2 kwietnia 1997 roku (Dz.U., nr 78, poz. 483 ze zm.).

2 Art. 2 Konstytucji RP.

3 T. Liszcz, W sprawie sprawiedliwości w prawie pracy, [w:] Aksjologiczne podstawy prawa pracy i ubezpieczeń społecznych, pod red. M. Skąpskiego, K. Ślebzaka, Poznań 2014, s. 111.

4 Ustawą z dnia 26 lipca 2002 roku o zmianie ustawy - Kodeks pracy oraz o zmianie niektórych innych ustaw (Dz.U., nr 135, poz. 1146) dodano do art. $25 \S 1$ k.p. zdanie drugie i równocześnie do art. 177 k.p. dodano nowy $\S 3^{1}$. 
nieobecności (art. $25 \S 1$ zd. 2 k.p.). Regulacja umowy na zastępstwo jest zdecydowanym udogodnieniem dla pracodawców, ponieważ umożliwia im rozwiązywanie problemów natury kadrowej w sytuacji okresowej niezdolności do pracy nieobecnego (stałego) pracownika. Nie sposób jednak nie zauważyć, iż w aktualnym kształcie modyfikacje, które dotyczą tej umowy w porównaniu z innymi umowami o pracę na czas określony uzasadniają twierdzenie, iż jest to umowa nie tylko zaprzeczająca podstawowym zasadom prawa pracy (równości, uprzywilejowania i korzystności), ale również ideom kreowanym przez demokratyczne państwo, takim jak równość w zatrudnieniu i sprawiedliwość społeczna. Wspomniane modyfikacje, tj. krótszy i sztywny okres wypowiedzenia czy nieprzedłużanie czasu trwania umowy do dnia porodu, budzą najwięcej kontrowersji i wątpliwości, stanowiąc przedmiot ożywionej dyskusji w doktrynie prawa pracy oraz oceny, również pod kątem niezgodności tej regulacji z prawem europejskims. Omówienie problematyki umów na zastępstwo w aspekcie zasady sprawiedliwości społecznej oraz zasady równości jawi się być interesujące także z uwagi na planowane w tym zakresie zmiany Kodeksu pracy ${ }^{6}$.

\section{ROLA ZASADY SPRAWIEDLIWOŚCI SPOŁECZNEJ I ZASADY RÓWNOŚCI W PRAWIE PRACY}

Termin „sprawiedliwość społeczna” posiada w nauce wiele różnych znaczeń $^{7}$, ale to sprawiedliwość rozdzielcza (redystrybutywna) wydaje się być najbardziej adekwatna do stosunków pracy, gdyż koresponduje z rozdzielczą funkcją prawa pracy ${ }^{8}$. Sama zasada sprawiedliwości społecznej bez uzupełnienia o inne regulacje konstytucyjne, jak słusznie zauważa A. Sobczyk ${ }^{9}$, nie ma jednak dla prawa pracy większej wartości poznawczej. Zyskuje ją dopiero wówczas, gdy połączymy ją z zasadą równości wobec prawa, dobra wspólnego i solidarności ${ }^{10}$. Szczególny związek istnieje pomiędzy zasadą sprawiedliwości a zasadą poszanowania godności człowieka. Każdy winien być traktowany bezstronnie i sprawie-

5 K. Walczak, Umowa na zastęstwo - czy można ja kwestionować za względu na niezgodność z prawem europejskim?, „Monitor Prawa Pracy” 2005, nr 3.

6 Projekt z dnia 19 marca 2015 roku o zmianie ustawy - Kodeks pracy oraz niektórych innych ustaw (w wersji na Radę Ministrów), www.mpips.gov.pl/archiwum-projekty-aktow-prawnych-/archiwum-projekty-ustaw/prawo-pracy/projekt-ustawy-o-zmianie-ustawy---kodeks-pracyoraz-niektorych-innych-ustaw-1 [data dostępu: 10.08.2015].

7 R. Szarfenberg, Teoria polityki społecznej. Teoria normatywna: sprawiedliwość społeczna, http://rszarf.ips.uw.edu.pl/tps/dzienne/w12sprawiedliwosc.pdf [data dostępu: 10.08.2015].

8 T. Liszcz, op. cit., s. 111.

9 A. Sobczyk, Prawo pracy w świetle Konstytucji RP, t. 1: Teoria publicznego i prywatnego indywidualnego prawa pracy, Warszawa 2013, s. 61.

10 Ibidem, s. 62. 
dliwie, wedle jednakowej dla wszystkich miary ${ }^{11}$. Godność człowieka jako źródło wolności i praw (art. 30 Konstytucji) uznaje się za fundament sprawiedliwości.

Zasada równości ma charakter uniwersalny, obejmuje każdą jednostkę, a tym samym osobę fizyczną i osobę prawną, oraz jednostki organizacyjne nieposiadające osobowości prawnej. Może występować zarówno jako zasada ustrojowa, jak i prawo podmiotowe, poza tym pozostaje w ścisłym związku z innymi zasadami (m.in. godnością człowieka, wolnością) i nie może być interpretowana bez uwzględnienia kontekstu aksjologicznego ${ }^{12}$. Równość traktowania i równość W stanowieniu prawa opierają się na założeniu, które polega na uznaniu, że podmioty podobne, a więc należące do tej samej klasy, należy traktować podobnie. Zróżnicowanie sytuacji podmiotów podobnych jest dopuszczalne tylko wtedy, gdy zostanie uzasadnione obiektywnie istniejącymi przesłankami i znajduje podstawy w sprawiedliwości społecznej ${ }^{13}$. Z kolei sprawiedliwość wymaga, aby zróżnicowanie ludzi pozostawało w odpowiedniej relacji do różnic w sytuacji tych ludzi (pracowników). Aby prawo było sprawiedliwe, nie może obyć się bez określonych kwalifikacji prawnych wprowadzających rozróżnienia za pośrednictwem szczegółowych norm. Jednak aby kryterium rozróżnienia mogło być uznane za uzasadnione i sprawiedliwe, należy ocenić, czy jego wybór był prawidłowy i adekwatny do sytuacji danej osoby (grupy). Zgodnie z orzecznictwem Trybunału Konstytucyjnego ${ }^{14}$ zasada równości polega na tym, że wszystkie podmioty prawa (adresaci norm prawnych), charakteryzujące się daną cechą istotną (relewantną), mają być traktowane równo, co oznacza zarówno zakaz dyskryminowania, jak i faworyzowania takich osób. Ustalenie, czy zasada równości rzeczywiście została w konkretnym przypadku naruszona, wymaga określenia kręgu adresatów, do których odnosi się budząca wątpliwości norma prawna oraz wskazania elementów określających ich sytuację, które są prawnie relewantne. Treść zasady sprawiedliwości społecznej jest ogólniejsza i bogatsza niż zasady równości. Z jednej strony wyznacza ona obowiązki o charakterze formalnym, nakazując równe traktowanie podmiotów równych oraz zakazując równego traktowania podmiotów nierównych, z drugiej wyznacza obowiązki o charakterze materialnym, polegające na nakazie ochrony i realizacji szeregu wartości konstytucyjnych, w tym solidarności społecznej i bezpieczeństwa socjalnego ${ }^{15}$. Zasada sprawiedliwości konkretyzuje i koryguje zasadę równości w szczególności przez ocenę prawidłowości doboru kryteriów ${ }^{16}$. Nietrafne byłoby utożsamienie zasady równości ze sprawie-

11 Orzeczenie TK z dnia 6 lipca 1999 roku, P 2/99, OTK ZU 1999, nr 5, poz. 103.

12 L. Garlicki, Polskie prawo konstytucyjne. Zarys wykladu, Warszawa 2004, s. 90.

13 M. Witkowska, Zasada równości w stosunkach pracy na tle orzecznictwa Trybunatu Konstytucyjnego, „Przegląd Prawa Konstytucyjnego” 2011, nr 1, s. 209.

14 Wyrok TK z dnia 14 lipca 2004 roku, SK 8/03, OTK ZU nr 7/A/2004, poz. 65.

15 Wyrok TK z dnia 19 grudnia 2012 roku, K 9/12, OTK ZU nr 11/A/2012, poz. 136.

16 Wyrok TK z dnia 24 maja 2006 roku, K 5/05, OTK-A 2006, nr 5, poz. 59. 
dliwością w tym znaczeniu, że zastosowanie zasady równości oznacza spełnienie warunku sprawiedliwości, a także, iż sprawiedliwość realizuje się przez równość. Właściwe jest więc stanowisko, według którego równość jest jednym z elementów sprawiedliwości, obok reguły nierówności ${ }^{17}$. Jakiekolwiek odstępstwa od nakazu równego traktowania podmiotów podobnych muszą znajdować obiektywne uzasadnienie, które winno mieć charakter relewantny oraz służyć realizacji celu $i$ treści przepisów ${ }^{18}$. Poza tym argumenty na rzecz różnicowania muszą mieć charakter proporcjonalny, a więc waga interesu, któremu ma służyć różnicowanie (prawa i interesy podmiotu zatrudniającego), musi pozostawać w odpowiedniej proporcji do wagi interesów, które zostaną naruszone w wyniku nierównego potraktowania podmiotów podobnych (prawa i interesy pracownika zatrudnionego na zastępstwo). Wreszcie argumenty te muszą pozostawać w związku z innymi wartościami, zasadami czy normami konstytucyjnymi, uzasadniającymi odmienne traktowanie podmiotów podobnych.

Jaka jest zatem różnica w sytuacji pracownika wykonującego pracę na podstawie umowy o pracę na czas określony od sytuacji pracownika zatrudnionego w oparciu o umowę o pracę na zastępstwo, która uzasadniałaby tak dalekie i jakże niesprawiedliwe różnicowanie? Czy odstępstwa w tym zakresie znajdują obiektywne uzasadnienie? Przecież każdy z tych pracowników ma świadomość co do terminowego charakteru pracy i godzi się na to, a więc ich sytuacja jest niepewna. Czy waga interesu ekonomicznego pracodawcy (ochrona elastycznego zatrudnienia) kontra interesy (ochrona stosunku pracy) pracownika zatrudnionego na zastępstwo (szczególnie kobiety w ciąży) pozostają w odpowiedniej proporcji? $\mathrm{W}$ moim przekonaniu taka różnica po prostu nie istnieje, a powoływanie się jedynie na różne cele, dla których zawiera się tego rodzaju umowy, absolutnie nie uzasadnia różnicowania. Proporcja pomiędzy interesami stron umowy o pracę na zastępstwo została całkowicie zachwiana.

Art. $11^{2}$ k.p. stanowi wprost, że pracownik ma takie prawa, jak inny znajdujący się w tej samej sytuacji (ma równe prawa) i nie ogranicza się ich do równości co do warunków umownych, ale odnosi do równości praw. Dlaczego zatem pracownik (zastępca), który wykonuje pracę taką samą i tak samo, jak inny pracownik (nieobecny), ma na gruncie Kodeksu pracy przyznane mniejsze prawa? Przecież niedopuszczalne jest różnicowanie sytuacji prawnej podmiotów, jeżeli ich sytuacja faktyczna jest taka sama ${ }^{19}$. W zasadzie różnica sprowadzać się może (ale wcale nie musi) jedynie do rodzaju umowy, ale już nie do rodzaju pracy. Niestety, poza tą różnicą, niemającą w tym przypadku większego znaczenia meryto-

17 M. Witkowska, op. cit., s. 207.

18 Ibidem, s. 210.

19 Orzeczenie TK z dnia 20 grudnia 1994 roku, K 8/94, OTK 2/1994, poz. 43; orzeczenie TK z dnia 28 listopada 1995 roku, K 17/95, OTK 2/1995, poz. 37. 
rycznego, nie znajduję racjonalnej argumentacji w odpowiedzi na tak postawione pytanie. Zdaje się, że cel (interes pracodawcy), dla którego zawiera się tego typu umowy, absolutnie przyćmił ocenę pod kątem zgodności z Konstytucją i zasadami prawa pracy. Jeżeli ustawodawca miał jedynie w zamiarze ułatwić pracodawcy czasowe „załatanie” dziury kadrowej, to winien możliwość taką uregulować zdecydowanie poza Kodeksem pracy. Wydaje się, iż trafionym rozwiązaniem w tego typu sytuacjach jest skorzystanie przez pracodawcę z agencji pracy tymczasowej i proponowanych w ustawie o zatrudnianiu pracowników tymczasowych ${ }^{20}$ form zatrudniania na czas określony. Różnicowanie sytuacji pracownika tymczasowego nie budzi kontrowersji i jest transparentne jako elastyczna forma zatrudnienia. $\mathrm{W}$ porównaniu $\mathrm{z}$ umową na czas zastępstwa instytucja ta oferuje dla pracodawców bardziej elastyczne rozwiązania, bo nie wymaga zatrudnienia zastępcy (pracownika tymczasowego), którego zatrudnia agencja pracy tymczasowej.

\section{CHARAKTER PRAWNY UMOWY O PRACĘ NA ZASTĘPSTWO}

Wątpliwości odnośnie charakteru prawnego umowy o pracę na zastępstwo istnieją w doktrynie prawa pracy po dziś dzień, o czym świadczą liczne, a zarazem różnorakie koncepcje. Począwszy od twierdzenia, iż umowa ta stanowi zupełnie nowy rodzaj ${ }^{21}$, a wręcz szczególny rodzaj ${ }^{22}$ umowy o pracę, o czym świadczy chociażby brak możliwości dokładnego oznaczenia czasu jej trwania, po uznanie jej jako szczególnej odmiany umowy o pracę na czas określony ${ }^{23}$. Umowa o zastępstwo pracownika, czyli umowa zawierana na czas usprawiedliwionej nieobecności pracownika, jest niewątpliwie umową o pracę należącą do grupy umów terminowych ${ }^{24}$. Zdecydowana większość wśród przedstawicieli doktryny opowiada się za traktowaniem tej umowy jako umowy o pracę na czas określony z pewnymi modyfikacjami ujętymi w przepisach Kodeksu pracy ${ }^{25}$, choć można napotkać również na opinię, że umowa na zastępstwo zbliża się w swojej konstrukcji do

${ }^{20}$ Ustawa z dnia 9 lipca 2003 roku o zatrudnianiu pracowników tymczasowych (Dz.U. z 2003 roku, nr 166, poz. 1608).

${ }_{21}$ Zob. K. Rączka, Kodeks pracy po zmianach, „Przegląd Ubezpieczeń Społecznych i Gospodarczych" 2002, nr 9, s. 5; D. Cichocka, Umowa o pracę na czas określony zawierana w celu zastępstwa pracownika $w$ czasie jego nieusprawiedliwionej nieobecności w pracy, [w:] Z problematyki prawa pracy i polityki socjalnej, t. 16, Katowice 2005, s. 35.

22 R. Sadlik, Umowa na zastępstwo jako rodzaj umowy o pracę na czas określony, „Przegląd Prawniczy" 2003, nr 2, s. 16 i n.

23 M. Gersdorf, [w:] Kodeks pracy. Komentarz, pod red. Z. Salwy, Warszawa 2008, s. 158.

24 Tak też: S. Ciupa, Umowa o pracę zawierana na czas nieobecności (zastępstwo) pracowni$k a$, ,Monitor Prawniczy” 2002, nr 24, s. 1120; D. Cichocka, op. cit., s. 23.

${ }_{25}$ K. Jaśkowski, [w:] Kodeks pracy. Komentarz; Z. Kubot, Umowa o pracę na zastępstwo, „Praca i Zabezpieczenie Społeczne” 2003, nr 2, s. 17 i n.; J. Litowski, Dopuszczalność wypowiadania umowy o prace na zastepstwo, „Monitor Prawa Pracy” 2010, nr 8. 
umowy na czas wykonywania określonej pracy ${ }^{26}$, a nawet do umowy o pracę na okres próbny, która z kolei zaliczana jest do umów o charakterze tymczasowym ${ }^{27}$. Zdaniem J. Litowskiego ${ }^{28}$ umowę tę traktować należy jako umowę o pracę na czas określony, zaś nie należy traktować jej ani jako szczególnego rodzaju umowę o pracę, ani jako specyficzną odmianę umowy o pracę.

Ustawodawca w projekcie o zmianie ustawy Kodeks pracy z marca 2015 roku zamierza definitywnie określić charakter prawny umowy o pracę na zastępstwo i nie definiować jej, traktując jako umowę o pracę zawieraną na czas określony. Skoro Kodeks pracy nie będzie już nazywał wprost umów na zastępstwo, to tym samym nie będzie można uznawać ich za osobny rodzaj umów o pracę. Umowa na zastępstwo będzie traktowana wyłącznie jako swego rodzaju podtyp umowy o pracę na czas określony. Taka zmiana, którą oceniam jako korzystną, pozwoli raz na zawsze jednoznacznie określić charakter prawny umowy na zastępstwo. Gdyby jednak do planowanych zmian Kodeksu pracy nie doszło, de lege lata z definicji zawartej w art. $25 \S 1$ zd. 2 k.p. w moim przekonaniu wprost wynika, że umowa o pracę na czas zastępstwa jest umową o pracę na czas określony.

Umowa na zastępstwo pracownika w porównaniu z innymi umowami terminowymi realizuje jedynie inny cel i funkcję określoną przede wszystkim interesem pracodawcy. Uważam, że poza mocno wyeksponowanym celem zawarcia takiej umowy nie istnieją, i tak naprawdę nigdy nie istniały, żadne podstawy do nadawania jej wyjątkowego czy też szczególnego charakteru prawnego. Pracodawca, zawierając umowę o pracę na czas zastępstwa, powinien wyraźnie ukształtować jej treść, jasno doprecyzować cel, dla którego umowa jest zawierana oraz wykazać konieczność ustanowienia zastępstwa. Ową konieczność kwalifikuje się jako potrzebę istotną, pilną, niecierpiącą zwłoki ${ }^{29}$. W razie wystąpienia sytuacji uzasadniającej zastępstwo decyzja o ewentualnym zatrudnieniu nowego pracownika będzie zależała od swobodnego uznania pracodawcy, dla którego „potrzeba” nie musi być równoznaczna z „koniecznością" ${ }^{30}$. Jeżeli jednak pracodawca nie wykaże racjonalnego powodu, dla którego zaistniała potrzeba zatrudnienia na zastępstwo, może liczyć się z zarzutem zawarcia umowy celem obejścia prawa ${ }^{31}$. Zawarcie umowy o pracę na zastępstwo ma służyć zaspokojeniu rzeczywistego zapotrzebowania o charakterze okresowym. Konieczne będzie określenie w umo-

26 S. Ciupa, op. cit., s. 1120.

27 B. Wagner, Terminowe umowy o pracę, Warszawa 1980, s. 8.

28 J. Litowski, op. cit.

29 S. Ciupa, op. cit., s. 1120.

30 Ibidem, s. 1121.

31 W wyroku z dnia 24 czerwca 2010 roku w sprawie C-98/09, zamieszczonym pod klauzulą 8 dyrektywy 1999/70, TS stwierdził, że umowa na zastępstwo nie musi zawierać nazwisk zastępowanych pracowników i powodu ich zastępowania i może ograniczać się do wskazania przyczyny, dla której została zawarta. 
wie o pracę celu lub okoliczności przez zamieszczenie stosownych informacji o przyczynach obiektywnie uzasadniających zawarcie umowy na zastępstwo ${ }^{32}$.

Nie można oczywiście zaprzeczyć, iż umowa o pracę na zastępstwo została w Kodeksie pracy normatywnie wyróżniona, z tym że nie miało to służyć podkreśleniu jej wyjątkowego charakteru, ale identyfikacji tej grupy umów o pracę na czas określony $^{33}$. Odrębności, a w zasadzie modyfikacje, które dotyczą tej umowy, w porównaniu z innymi umowami o pracę nie czynią jej wyjątkową. Owe modyfikacje, tj. krótszy i sztywny okres wypowiedzenia czy nieprzedłużanie czasu jej trwania do dnia porodu, budzą najwięcej kontrowersji i wątpliwości. Ustawodawca, planując aktualnie zmiany w Kodeksie pracy, próbuje zmierzyć się ze wszystkimi problemami w zakresie umów terminowych, w tym umów na zastępstwo, ale niestety zmiany wydają się być jedynie częściowe. Z jednej strony zamierza się przesądzić o charakterze umowy na zastępstwo, dążąc jednocześnie do kompleksowego uregulowania możliwości i zakresu dopuszczalności jej wypowiadania, ale $\mathrm{w}$ dalszym ciągu całkowicie pomija się uprawnienia kobiet w ciąży pracujących w oparciu o tego rodzaju umowę o pracę.

\section{ZASADY WYPOWIADANIA UMOWY NA ZASTECPSTWO - UWAGI DE LEGE LATA I DE LEGE FERENDA}

Istnieją dwie koncepcje co do możliwości wypowiadania umowy o pracę na zastępstwo. Jedna z nich zakłada, że art. $33^{1}$ k.p. stanowi samodzielną podstawę wypowiedzenia niezależnie od treści umowy o pracę i czasu jej trwania ${ }^{34}$. Druga, opierająca się na wykładni językowej i systemowej, uznaje, że art. $33^{1}$ k.p. kształtuje wyłącznie długość okresu wypowiedzenia, ale nie wyłącza jednoczesnego stosowania art. 33 k.p. ${ }^{35}$ Wyodrębnienie przez ustawodawcę art. $33^{1}$ k.p. zdaje się świadczyć o tym, że nie chodzi w tym przepisie tylko o ustalenie długości okresu wypowiedzenia, ale również o wprowadzenie dopuszczalności wypowiedzenia każdej umowy na zastępstwo ${ }^{36}$. De lege ferenda należałoby się zgodzić z dopuszczalnością wypowiadania tych szczególnych umów na czas określony, de lege lata wniosek taki nie przekonuje. W art. $33^{1}$ k.p. mowa jest jedynie o tym, że okres wypowiedzenia umowy na zastępstwo wynosi 3 dni robocze. Zdaniem Sądu Najwyższego nie można nie przyjąć, że warunki do-

32 Art. $29 \S 1^{1}$ projektu z dnia 19 marca 2015 roku.

33 J. Litowski, op. cit.

34 R. Sadlik, Nie znasz dnia ani godziny rozstania. Różnice miedzy umowa o pracę na zastępstwo a umowa na czas określony, „Rzeczpospolita”, 29.05.2012, http://prawo.rp.pl/artykul/793334,882963.html [data dostępu: 10.08.2015]; D. Cichocka, op. cit., s. 30.

35 Por. M. Gersdorf, op. cit., s. 204; K. Jaśkowski, op. cit.; D. Cichocka, op. cit., s. 32; J. Litowski, op. cit.

36 Z. Góral, Komentarz do art. 33 k.p., [w:] Komentarz. Kodeks pracy, LEX 2012. 
puszczalności wypowiedzenia takiej umowy jako umowy na czas określony są wskazane w art. 33 k.p. ${ }^{37}$

Mając na uwadze słuszność zapatrywań dotyczących uznania umowy o pracę na zastępstwo jako umowy o pracę na czas określony, przyjmuję, że w przypadku umowy na zastępstwo zawartej na okres krótszy niż 6 miesięcy zastosowanie znajdzie art. $33^{1}$ k.p. z 3-dniowym okresem wypowiedzenia, bez konieczności wprowadzania dodatkowych zapisów umownych. Przy umowach na zastępstwo, które mogłyby trwać dłużej niż 6 miesięcy, konieczne byłoby wprowadzenie klauzuli o 2-tygodniowym wypowiedzeniu, tym samym stosując wprost rozwiązania przewidziane w art. 33 k.p. Identyczne zapatrywania przedstawił K. Walczak ${ }^{38}$, wskazując na konieczność doprowadzenia do zgodności umowy na zastępstwo z wymogami ratyfikowanej przez Polskę konwencji Rady Europy.

Powyższe sugestie i uwagi de lege ferenda nie idą jednak w parze $\mathrm{z}$ tym, co w projekcie do Kodeksu pracy zamierza ustawodawca. Decyduje się on na uchylenie art. 33 k.p. oraz art. $33^{1}$ k.p. Zaproponowane zmiany oceniać należy całościowo i w kontekście głównych założeń projektu, które mają na celu ograniczenie nieuzasadnionego wykorzystywania umów o pracę na czas określony zawieranych bez obiektywnego uzasadnienia na długie okresy.

W art. $32 \S 1$ k.p. wskazuje się, iż każda ze stron może rozwiązać za wypowiedzeniem umowę o pracę zawartą na okres próbny i czas nieokreślony. Z kolei możliwość wypowiedzenia umowy o pracę zawartej na czas określony (i to nie każdej) została uzależniona od wprowadzenia do jej treści stosownej klauzuli, zaś sam okres wypowiedzenia ma charakter sztywny i niezależny od stażu pracy u danego pracodawcy. Po zmianie przepisów ustawodawca chce, aby możliwość rozwiązania umowy o pracę za wypowiedzeniem istniała bez względu na rodzaj zawartej umowy, zaś okres wypowiedzenia zarówno umowy o pracę na czas nieokreślony, jak i umowy o pracę na czas określony był uzależniony od okresu zatrudnienia u danego pracodawcy ${ }^{39}$. Proponowane zmiany stały się konieczne m.in. z uwagi na wyrok Trybunału Sprawiedliwości UE ${ }^{40}$, w którym uznano sprzeczność naszych krajowych rozwiązań z prawem unijnym, a to z uwagi na nierówne traktowanie pracowników zatrudnionych na czas określony i nieokreślony.

Komentowany projekt zakłada radykalną zmianę w zakresie zasad wypowiadania umów o pracę na czas określony. Przede wszystkim umowy o pracę

37 Taką wykładnię podziela również Sąd Najwyższy w uzasadnieniu wyroku z dnia 3 grudnia 2009 roku, II PK 142/09, SNP 2011/11-12/153.

38 K. Walczak, op. cit.

39 Art. $36 \S 1$ projektu z dnia 19 marca 2015 roku.

40 Wyrok TSUE z dnia 13 marca 2014 roku, C-38/13, stanowisko Trybunału znajduje potwierdzenie w orzecznictwie Sądu Najwyższego. Zob. także: wyrok SN z dnia 5 czerwca 2014 roku, I PK 308/13, LEX nr 1475061; wyrok SN z dnia 7 września 2005 roku, II PK 294/04, OSNP 2006/13-14/207. 
na czas określony mogłyby być rozwiązywane za wypowiedzeniem w każdym przypadku, bez ograniczeń dotyczących czasu trwania umowy czy konieczności wprowadzenia do umowy specjalnej klauzuli, z zachowaniem takich samych okresów wypowiedzenia, jak w przypadku wypowiadania umów o pracę na czas nieokreślony, czyli uzależnionych od czasu trwania stażu pracy pracownika u danego pracodawcy. Zmiana dotyczyłaby wszystkich umów o pracę na czas określony, a więc również umowy na czas zastępstwa pracownika, z tym że okres wypowiedzenia przy umowie na zastępstwo będzie miał zastosowanie, gdy pracodawca wypowiada umowę o pracę pracownikowi zastępcy, ale nie jest konieczne wypowiedzenie takiej umowy, gdy do pracy powraca zastępowany pracownik ${ }^{41}$. Wówczas umowa o pracę na czas określony zawarta w celu zastępstwa rozwiązuje się z dniem poprzedzającym dzień powrotu zastępowanego pracownika, co wynika z samej istoty tej umowy.

Proponowane zmiany w Kodeksie pracy pokazują, iż brak możliwości dokładnego oznaczenia czasu trwania umowy na zastępstwo nie stanowi już przeszkody w uznaniu i traktowaniu jej jako zawieranej na czas oznaczony. Ustanie stanu usprawiedliwionej nieobecności pracownika wyznacza koniec czasu trwania tej umowy, a to jako zdarzenie przyszłe i pewne mieści się w doktrynalnym pojęciu terminu ${ }^{42}$. W zasadzie można przewidzieć to, kiedy usprawiedliwiona nieobecność dobiegnie końca, gdyż albo wynika to z przepisów prawa, albo z ustaleń stron stosunku pracy, z informacji przekazywanych przez nieobecnego pracownika lub z dokumentów usprawiedliwiających jego nieobecność ${ }^{43}$. Pomimo że zmiany do Kodeksu pracy są dopiero w fazie projektu, spotkały się już z krytyką przedstawicieli pracodawców, którzy zdecydowanie opowiadają się za utrzymaniem odrębności umowy na zastępstwo przez zachowanie obecnie obowiązującego, sztywnego okresu wypowiedzenia nieuzależnianego od pracy u danego pracodawcy. Nie jest zasadne traktowanie tej umowy na równi z typową umową na czas określony, gdyż inny jest zarówno cel, jak i długość jej trwania ${ }^{44}$. Uważam, że ani cel umowy, ani czas jej trwania nie mogą stanowić kryterium uzasadniającego tak daleko idące różnicowanie pracowników.

${ }^{41}$ Wątpliwości mogą pojawić się, gdy z pracownikiem zastępowanym pracodawca będzie chciał rozwiązać umowę o pracę w trybie art. 53 k.p. Skoro nie powróci on już do pracy, to cel zawarcia umowy o pracę na zastępstwo przestaje istnieć i trudno jest ustalić, do kiedy taka umowa miałaby trwać. W takim przypadku słuszne wydaje się rozwiązanie umowy o pracę na zastępstwo dokładnie w momencie skutecznego rozwiązania umowy o pracę z zastępowanym pracownikiem.

42 J. Litowski, op. cit.

43 S. Ciupa, op. cit.

44 Pracodawcy chca zmian $w$ umowach terminowych. Informacja prasowa, Warszawa, 21 listopada $2014 \mathrm{roku}$, www.dolnoslascypracodawcy.pl/upload/upload/20141121\%20Pracodawcy\%20 chc\%C4\%85\%20zmian\%20w\%20umowach\%20terminowych.pdf [data dostępu: 10.08 .2015 ]. 


\section{SYTUACJA PRACOWNICY W CIĄŻY ZATRUDNIONEJ NA CZAS USPRAWIEDLIWIONEJ NIEOBECNOŚCI}

Osoba zastępująca nieobecnego pracownika (zastępca) przez nawiązanie z podmiotem zatrudniającym (pracodawcą) umowy o pracę na zastępstwo uzyskuje status pracownika w rozumieniu art. 2 k.p. Zastępca pozostaje zobowiązany do wykonywania na rzecz pracodawcy i za wynagrodzeniem pracy, którą dotychczas wykonywał nieobecny pracownik, pod kierownictwem i w miejscu wyznaczonym przez pracodawcę, $\mathrm{z}$ tą widoczną różnicą, że sytuacja prawna pracownika zastępcy jest zupełnie inna niż pracowników zatrudnionych na podstawie umów terminowych czy umów bezterminowych. Uzasadnia się to celem i funkcją, jaką wypełnia umowa na zastępstwo oraz sposobem jej ustania. Celem tej umowy jest czasowe zastępstwo innego pracownika wyłącznie w czasie jego usprawiedliwionej nieobecności, zaś termin końcowy zostaje wyznaczony powrotem do pracy zastępowanego pracownika. W związku z tym trwałość tej umowy jest z góry „,naruszona”, i to w sposób najdalej idący w grupie terminowych umów o pracę ${ }^{45}$. Zdaniem S. Ciupy umowy na czas określony i na czas wykonywania określonej pracy też kiedyś ustają, ale ich trwałość ma stabilniejsze podstawy, a pracownik ma silniejsze gwarancje trwania stosunku pracy. Nie przychylam się do takiej argumentacji, ponieważ Kodeks pracy nie wprowadza ani minimalnego, ani maksymalnego terminu, na jaki umowa na czas określony może być zawarta ${ }^{46}$. Owa stabilność umów na czas określony ma zatem charakter jedynie iluzoryczny ${ }^{47}$. W mojej ocenie ,inność" sytuacji prawnej osób zatrudnionych na zastępstwo oznacza po prostu ich słabszą ochronę, a w pewnych przypadkach całkowity jej brak, co uznaję za niedopuszczalne z perspektywy zasady równości i sprawiedliwości. Szczególnie widoczne jest to w przypadku kobiety w ciąży, kiedy ustawodawca automatycznie uchyla możliwość przedłużenia czasu trwania tej umowy do dnia porodu (art. $177 \S 3$ k.p.). Twierdzenia zaś, iż jest to uzasadnione celem umowy i jej funkcją zdecydowanie uznaje za mało przekonywujące i niewystarczające.

W jakim celu zatem wprowadzono do Kodeksu pracy umowę o pracę na zastępstwo, skoro nie zapewnia się pracownikowi (zastępcy) ochrony i bezzasadnie

45 S. Ciupa, op. cit.

46 W wyniku najnowszych zmian Kodeksu pracy po dniu 22 lutego 2016 roku ustawodawca wprowadził limit czasowy zatrudniania na podstawie umowy (umów) na czas określony wynoszący 33 miesiące oraz limit ilościowy umów tego rodzaju wynoszący maksymalnie 3 umowy. Limity te będą dotyczyły zatrudnienia między tymi samymi stronami. Konsekwencją ich przekroczenia będzie przekształcenie umowy na czas określony w umowę na czas nieokreślony. Pracodawcy nie będą zobowiązani do stosowania limitów m.in. w przypadku zawarcia umowy na czas określony w celu zastępstwa innego pracownika.

47 Projekt z dnia 19 marca 2015 roku o zmianie ustawy - Kodeks pracy oraz niektórych innych ustaw zakłada ograniczenie zawierania umów o pracę na czas określony nie tylko co do liczby, ale również ograniczenia czasowe. 
różnicuje jego sytuację? Jeżeli umowa o pracę na zastępstwo jest traktowana jako rodzaj umowy o pracę na czas określony, to wydaje się, iż różnice co do możliwości wypowiedzenia tej umowy czy ochrony kobiety w ciąży nie powinny istnieć. Wprawdzie w Kodeksie pracy pomiędzy poszczególnymi rodzajami umów terminowych zachodzą istotne różnice jeżeli chodzi o cele, czas trwania, stabilizację zatrudnienia, a także sposób oznaczenia terminu końcowego ${ }^{48}$, ale jednocześnie wszystkie te umowy nie różnicują i nie zapewniają kobiecie w ciąży pełnej ochrony przewidzianej przepisami prawa pracy. Nawet pracownica zatrudniona w oparciu o umowę na okres próbny, czyli umowę terminową, ale niebędącą przecież umową na czas określony, korzysta $z$ analogicznej ochrony, jak pracownica zatrudniona w oparciu o umowę na czas określony. Dlaczego więc ustawodawca różnicuje pracownice w ciąży zatrudnione w oparciu o, jakby nie było, ten sam rodzaj umowy o pracę? Tylko dlatego, że cel zawarcia tych umów jest inny i tylko dlatego, że umowa na zastępstwo zawierana jest w interesie pracodawcy? Przecież cel umowy o pracę na okres próbny ${ }^{49}$ także jest inny niż umowy o pracę na czas określony.

Kobiety w ciąży zatrudnione w oparciu o umowę na zastępstwo pozostają objęte szczególną ochroną stosunku pracy, o której mowa w art. 177 § 1 k.p. Pracodawca nie może w okresie ciąży pracownicy zastępcy wypowiedzieć ani rozwiązać wypowiedzianej umowy o pracę na czas zastępstwa. Oznacza to, że w przypadku umowy na czas zastępstwa ochrona trwałości stosunku pracy została zapewniona kobiecie w ciąży i rozpoczyna się ona od początku ciąży, ale z woli ustawodawcy kończy wraz z nadejściem terminu, na jaki zawarta była umowa. W związku z tym powstaje pytanie, czy ochronę taką można uznać za wystarczającą? W mojej opinii zdecydowanie nie. Wyłączenie, w stosunku do kobiety w ciąży zatrudnionej na podstawie umowy o pracę na zastępstwo, ochrony gwarantowanej przez art. 177 $\S 3$ k.p. uznaję za całkowicie bezzasadne. Pracownicy zatrudniani w celu zastępstwa innego pracownika w czasie jego usprawiedliwionej nieobecności pozostają, bez wątpienia, grupą pod najsłabszą ochroną prawa pracy.

Dopuszczalne jest - w płaszczyźnie art. 32 Konstytucji - istnienie różnic w treści poszczególnych typów umów o pracę, które wynikają wprost ze społecznej funkcji tych umów i ich ekonomicznej treści ${ }^{50}$. Dodatkowo wymaga podkreślenia, że art. $10 \S 3$ k.p., odwołujący się wprost do art. 65 ust. 5 Konstytucji, stanowi, że „Państwo prowadzi politykę zmierzającą do pełnego produktywnego zatrudnienia”. Możliwość sterowania procesami zatrudniania, uelastycznienia rynku pracy osiąga się również przez zróżnicowanie form zatrudnienia. Za uzasadnione należy uznać takie zróżnicowanie przez ustawodawcę form prawnych

\footnotetext{
48 Z. Kubot, Umowa o prace..., s. 20.

49 Wyrok SN z dnia 4 września 2013 roku, II PK 358/12, LEX nr 1460947.

50 Wyrok TK z dnia 2 grudnia 2008 roku, P 48/07, OTK-A 2008/10/173, Dz.U.2008/219/1409.
} 
świadczenia pracy, które daje maksymalnej liczbie osób szansę na podjęcie zatrudnienia przy jednoczesnym wprowadzeniu należytej ochrony praw pracowniczych. Nie jest jednak możliwe, zdaniem Trybunału Konstytucyjnego, osiągnięcie w wypadku umów czasowych takiego standardu ochrony, jak w wypadku umów na czas nieokreślony, gdyż przeczyłoby to celowi wprowadzenia przez ustawodawcę rozróżnienia tych umów, usztywniłoby system prawa pracy i w efekcie prowadziłoby do zmian odwrotnych od postulowanych. De lege lata nie sposób dyskutować z powyższym poglądem, ale jednocześnie należy mieć na względzie, iż dotyczył on oceny różnic w zakresie umowy terminowej i bezterminowej. Mając jednak na uwadze planowane przez ustawodawcę zmiany przez zrównanie szans i sytuacji pracowników zatrudnionych na umowach terminowych z pracownikami zatrudnionymi na czas nieokreślony, co do okresu ich wypowiedzenia, powołane orzeczenie TK winno ulec stosownej modyfikacji.

Dlaczego więc ustawodawca w przypadku umowy o pracę na zastępstwo tak bardzo różnicuje sytuację pracowników zatrudnionych w oparciu o ten sam typ (rodzaj) umowy o pracę? Umowa na zastępstwo traktowana jest przecież jako umowa o pracę na czas określony ${ }^{51}$, a mimo to kobiety w ciąży nie korzystają $\mathrm{z}$ ochrony przewidzianej w art. $177 \S 3$ k.p. Ustawodawca zasłania się zarówno celem, dla którego umowa ta jest zawierana, jak i niepewnym czasem jej trwania. Zgadzam się, że prawo pracy musi odmiennie kształtować sytuacje poszczególnych pracowników ze względu na wykonywaną przez nich pracę, a także ze względu na ich cechy osobowe. Niestety, nie dostrzegam odmienności pomiędzy wykonywaniem pracy przez pracowników zatrudnionych na zastępstwo a tymi zatrudnionymi na czas określony, ani też odmienności w cechach osobowych tych grup pracowniczych, które uzasadniałyby różnicowanie.

Przedstawiciele doktryny ${ }^{52}$, którzy podejmują próbę zmierzenia się z tym tematem podnoszą, iż rozciągnięcie ochrony mogłoby nałożyć na pracodawcę obowiązek podwójnego zatrudnienia, co przeczy idei umów na zastępstwo. Faktycznie, w momencie powrotu pracownika zastępowanego, którego pracodawca winien przyjąc do pracy, i jednoczesnej ciąży pracownicy zastępcy, której umowa miałaby trwać do dnia porodu, doszłoby do obowiązku zatrudnienia dwóch osób na jednym stanowisku pracy, z tym że pracodawca, zatrudniając zastępcę, wcale nie pozostaje związany warunkami wynikającymi z umowy z pracownikiem zastępowanym. Skoro nie ma obowiązku zawarcia umowy o zastępstwo na identycznych warunkach, to określając z pracownikiem zastępcą rodzaj pracy wykonywanej przez niego w okresie zastępstwa, można nakreślić go na tyle szeroko (przez odpowiednie

${ }^{51}$ Zarówno przez zdecydowaną większość wśród przedstawicieli doktryny w świetle obowiązujących przepisów Kodeksu pracy, jak i w kontekście projektowanych zmian, gdzie zamierza się uregulować charakter prawny umów o pracę na zastępstwo jako umów na czas określony.

52 S. Ciupa, op. cit. 
ukształtowanie zakresu czynności), aby uniknąć dublowania wykonywanych przez pracowników zadań nawet w ramach tego samego rodzaju pracy. Jak zauważa Z. Kubot ${ }^{53}$, umowa o pracę na zastępstwo nie może obejmować pracy dwurodzajowej czy wielorodzajowej, jeżeli zastępowany pracownik świadczy pracę jednego rodzaju. Popieram prezentowane stanowisko, ale jednocześnie dopuszczam wielozadaniowość w ramach jednego rodzaju pracy, którą w sytuacji szczególnej można podzielić pomiędzy dwóch pracowników. Można także pracownikowi powracającemu do pracy powierzyć tymczasowo inną pracę (art. 42 § 4 k.p.).

Spójrzmy na sytuację pracodawcy, który zatrudnia kobietę w oparciu o umowę na czas określony lub umowę na okres próbny. Kiedy pracownica zachodzi w ciążę, to na pracodawcy spoczywa ustawowy obowiązek dalszego jej zatrudnienia do dnia porodu, co oznacza, iż tak naprawdę mamy do czynienia z, ,przymusem zatrudnienia" 54 - wbrew woli pracodawcy, który może nie chcieć kontynuować współpracy z taką kobietą albo może być niezadowolony z pracy takiej pracownicy w okresie próbnym, ale musi utrzymać i kontynuować zatrudnienie. Taki „przymus zatrudnienia” nie tylko przeczy zasadzie dobrowolności, ale również może naruszyć interesy takiego pracodawcy. Nie uznaję za słuszne obarczania pracodawcy obowiązkiem utrzymania zatrudnienia, a wręcz przeciwnie - w takiej sytuacji obowiązki winno przejąć państwo. Pozostaję jednak w przekonaniu, że skoro osoba zatrudniona na zastępstwo uzyskuje statut pracownika, to winna podlegać standardom pracy dającym gwarancję pewności zatrudnienia i ochrony, potrzebnej kobiecie szczególnie w okresie ciąży ${ }^{55}$. Uznaję za uzasadnione różnicowanie form zatrudnienia, które dają maksymalnej liczbie osób szansę na podjęcie zatrudnienia, ale przy jednoczesnym wprowadzeniu należytej ochrony praw pracowniczych, której w przypadku umów na zastępstwo zdecydowanie brakuje. Osoba zastępująca, zatrudniona w oparciu o umowę terminową, której ustawodawca zamierza ostatecznie określić charakter prawny, winna korzystać z pełnych gwarancji i ochrony, jakie przepisy prawa przewidują dla pracowników zatrudnionych na umowie o pracę na czas określony. Z kolei jakiekolwiek odstępstwa nie mogą być dla pracowników krzywdzące i nie należy wywodzić ich jedynie z samego charakteru lub celu zawarcia umowy na zastępstwo ${ }^{56}$. Uznaję, iż art. $177 \S 3$ k.p. w zakresie, w jakim nie przewiduje możliwości przedłużenia umowy do dnia porodu kobiecie zatrudnionej na zastępstwo, jest niezgodny z art. 2 Kon-

53 Z. Kubot, Umowy o świadczenie pracy różnego rodzaju, „Państwo i Prawo” 1999, nr 10, s. 57 i n.

54 A. Sobczyk, Prawo pracy w świetle Konstytucji RP, t. 2: Wybrane problemy i instytucja prawa pracy a konstytucyjne prawa $i$ wolności człowieka, Warszawa 2013, s. 202-203.

55 Pod koniec 2014 roku do Ministerstwa Pracy i Polityki Społecznej została skierowana interpelacja nr $27640 \mathrm{w}$ sprawie naruszania prawa kobiet zatrudnionych na zastępstwo do ochrony w czasie ciąży (,Monitor Prawa Pracy” 2004, nr 12).

56 J. Litowski, op. cit. 
stytucji, w części wyrażającej zasadę sprawiedliwości społecznej, oraz z art. 32 Konstytucji, ustanawiającym zasadę równości.

W mojej ocenie de lege lata wyraźnie dochodzi do naruszenia zasady równości w zatrudnieniu, de lege ferenda ustawodawca winien zapewnić kobietom w ciąży zatrudnionym na zastępstwo analogiczną ochronę, jak kobietom w ciąży zatrudnionym na czas określony, a zatem wydłużyć umowę o pracę na zastępstwo do dnia porodu. Pozostaję w przekonaniu, że rozwiązanie takie, mimo wszystko, nie naruszy interesów pracodawcy i nie będzie dotyczyło kobiety, której umowa uległaby rozwiązaniu przed trzecim miesiącem ciąży. Należy zwrócić uwagę na to, iż kobieta w ciąży, zatrudniona na podstawie umowy na zastępstwo, może zostać pozbawiona nie tylko świadczeń pracowniczych, ale też świadczeń z tytułu ubezpieczeń społecznych. Taka konstrukcja przepisów przeczy ideom państwa, które stawia na macierzyństwo i narusza zasady sprawiedliwości społecznej. Jeżeli jednak nie sposób zapewnić takim kobietom lepszej ochrony pracy, to de lege lata pracownice te winny być zabezpieczone społecznie w stosowne świadczenia oraz zasiłki z tytułu macierzyństwa ${ }^{57}$.

\section{ZAKOŃCZENIE}

Istniejące obecnie w Kodeksie pracy uprawnienia przewidziane dla pracowników zatrudnionych w oparciu o umowę na zastępstwo, a w zasadzie ich brak, jeżeli chodzi o ochronę kobiet w ciąży, nie zachęcają do podjęcia zatrudnienia w oparciu o ten rodzaj umowy o pracę. Regulacja umowy na zastępstwo budzi szereg zastrzeżeń i bez wątpienia winna ulec zmianom. Niesprawiedliwe różnicowanie sytuacji prawnej tej grupy pracowników godzi w zasady prawa pracy i Konstytucję. Wprawdzie planowane przez ustawodawcę zmiany napawają optymizmem, ale nie rozstrzygają wszystkich wątpliwości i problemów. Widoczny jest w nich brak konsekwencji, gdyż z jednej strony ustawodawca zamierza przesądzić o charakterze tych umów, a z drugiej nie zrównuje szans kobiet w ciąży w ochronie zatrudnienia. W moim przekonaniu umowa o pracę na zastępstwo, na skutek planowanych zmian, zostanie stopniowo wyparta z praktyki jako niekorzystna dla pracownika forma zatrudnienia.

\section{BIBLIOGRAFIA}

Cichocka D., Umowa o pracę na czas określony zawierana w celu zastępstwa pracownika w czasie jego nieusprawiedliwionej nieobecności w pracy, [w:] Z problematyki prawa pracy i polityki socjalnej, t. 16, Katowice 2005.

Ciupa S., Umowa o pracę zawierana na czas nieobecności (zastępstwo) pracownika, „Monitor Prawniczy" 2002, nr 24.

57 K. Nowosielska, Zwolnienie ciężarnej możliwe, gdy ma umowę na zastępstwo, „Rzeczpospolita", 21.07.2014, http://prawo.rp.pl/artykul/1126925.html [data dostępu: 10.08.2015]. 
Garlicki L., Polskie prawo konstytucyjne. Zarys wyktadu, Warszawa 2004.

Gersdorf M., [w:] Kodeks pracy. Komentarz, pod red. Z. Salwy, Warszawa 2008.

Góral Z., Komentarz do art. 33 k.p., [w:] Komentarz. Kodeks pracy, LEX 2012.

Jaśkowski K., [w:] Kodeks pracy. Komentarz, pod red. Z. Salwy, Warszawa 2008.

Konstytucja Rzeczypospolitej Polskiej z dnia 2 kwietnia 1997 roku (Dz.U., nr 78, poz. 483 ze zm.).

Kubot Z., Umowa o prace na zastępstwo, „Praca i Zabezpieczenie Społeczne” 2003, nr 2.

Kubot Z., Umowy o świadczenie pracy różnego rodzaju, „Państwo i Prawo” 1999, nr 10.

Liszcz T., W sprawie sprawiedliwości w prawie pracy, [w:] Aksjologiczne podstawy prawa pracy i ubezpieczeń społecznych, pod red. M. Skąpskiego, K. Ślebzaka, Poznań 2014.

Litowski J., Dopuszczalność wypowiadania umowy o pracę na zastęstwo, „Monitor Prawa Pracy” 2010, $\mathrm{nr} 8$.

Nowosielska K., Zwolnienie ciężarnej możliwe, gdy ma umowę na zastępstwo, „Rzeczpospolita”, 21.07.2014, http://prawo.rp.pl/artykul/1126925.html [data dostępu: 10.08.2015].

Orzeczenie TK z dnia 20 grudnia 1994 roku, K 8/94, OTK 2/1994, poz. 43.

Orzeczenie TK z dnia 28 listopada 1995 roku, K 17/95, OTK 2/1995, poz. 37.

Orzeczenie TK z dnia 6 lipca 1999 roku, P 2/99, OTK ZU 1999, nr 5, poz. 103.

Pracodawcy chca zmian $w$ umowach terminowych. Informacja prasowa, Warszawa, 21 listopada $2014 \mathrm{roku}$, www.dolnoslascypracodawcy.pl/upload/upload/20141121\%20Pracodawcy\%20 chc\%C4\%85\%20zmian\%20w\%20umowach\%20terminowych.pdf [data dostępu: 10.08.2015].

Projekt z dnia 19 marca 2015 roku o zmianie ustawy - Kodeks pracy oraz niektórych innych ustaw (w wersji na Radę Ministrów), www.mpips.gov.pl/archiwum-projekty-aktow-prawnych-/archiwum-projekty-ustaw/prawo-pracy/projekt-ustawy-o-zmianie-ustawy---kodeks-pracy-orazniektorych-innych-ustaw-1 [data dostępu: 10.08.2015].

Rączka K., Kodeks pracy po zmianach, „Przegląd Ubezpieczeń Społecznych i Gospodarczych” 2002, $\mathrm{nr} 9$.

Sadlik R., Nie znasz dnia ani godziny rozstania. Różnice miedzy umowa o pracę na zastępstwo a umowa na czas określony, „Rzeczpospolita”, 29.05.2012, http://prawo.rp.pl/artykul/793334,882963.html [data dostępu: 10.08.2015].

Sadlik R., Umowa na zastępstwo jako rodzaj umowy o pracę na czas określony, „Przegląd Prawniczy" 2003, nr 2.

Sobczyk A., Prawo pracy w świetle Konstytucji RP, t. 1: Teoria publicznego i prywatnego indywidualnego prawa pracy, Warszawa 2013.

Sobczyk A., Prawo pracy w świetle Konstytucji RP, t. 2: Wybrane problemy i instytucja prawa pracy a konstytucyjne prawa i wolności człowieka, Warszawa 2013.

Szarfenberg R., Teoria polityki społecznej. Teoria normatywna: sprawiedliwość społeczna, http:// rszarf.ips.uw.edu.pl/tps/dzienne/w12sprawiedliwosc.pdf [data dostępu: 10.08.2015].

Ustawa z dnia 26 lipca 2002 roku o zmianie ustawy - Kodeks pracy oraz o zmianie niektórych innych ustaw (Dz.U., nr 135, poz. 1146).

Ustawa z dnia 9 lipca 2003 roku o zatrudnianiu pracowników tymczasowych (Dz.U. z 2003 roku, nr 166, poz. 1608).

Wagner B., Terminowe umowy o prace, Warszawa 1980.

Walczak K., Umowa na zastępstwo - czy można ja kwestionować za względu na niezgodność z prawem europejskim?, „Monitor Prawa Pracy” 2005, nr 3.

Witkowska M., Zasada równości w stosunkach pracy na tle orzecznictwa Trybunatu Konstytucyjnego, „Przegląd Prawa Konstytucyjnego” 2011, nr 1.

Wyrok SN z dnia 7 września 2005 roku, II PK 294/04, OSNP 2006/13-14/207.

Wyrok SN z dnia 3 grudnia 2009 roku, II PK 142/09, SNP 2011/11-12/153.

Wyrok SN z dnia 4 września 2013 roku, II PK 358/12, LEX nr 1460947.

Wyrok SN z dnia 5 czerwca 2014 roku, I PK 308/13, LEX nr 1475061.

Wyrok TK z dnia 14 lipca 2004 roku, SK 8/03, OTK ZU nr 7/A/2004, poz. 65. 
Wyrok TK z dnia 24 maja 2006 roku, K 5/05, OTK-A 2006, nr 5, poz. 59.

Wyrok TK z dnia 2 grudnia 2008 roku, P 48/07, OTK-A 2008/10/173, Dz.U.2008/219/1409.

Wyrok TK z dnia 19 grudnia 2012 roku, K 9/12, OTK ZU nr 11/A/2012, poz. 136.

Wyrok TSUE z dnia 13 marca 2014 roku, C-38/13.

\section{SUMMARY}

Employment contracts for replacement purposes are not legally clearly defined under the current Polish Labour Code. It is a contractual arrangement that allows employers to solve personnel issues associated with temporarily unavailable workers for given periods of time. The core elements associated with an employment contract for a replacement, as compared to those of a fixed term employment contract, warrant the assertion that this is an agreement incompatible with the principle of equality in employment and social justice. There are controversies also associated as to how such replacement agreements can be terminated. The legislator intends to change the governing rules of terminating fixed term contracts as well as replacement agreements. Those employees who are in fact replacing workers who are absent for justifiable reasons, remain the weakest employee group as far as employment law protection is concerned.

Keywords: replacement employment contracts; fixed-term contracts; termination of replacement contracts; pregnant women; equality; fair employment 